\title{
Women Legislators Capacity Building in South Sumatera: Case Study on People's Representative Council Provincial and District/City level)
}

\author{
Retno Susilowati* \\ Department of Political and Social \\ Sciences \\ Sriwijaya University \\ Palembang, Indonesia \\ retnosusilowati.yh@gmail.com
}

\author{
Nengyanti Nengyanti \\ Department of Political and Social \\ Sciences \\ Sriwijaya University \\ Palembang, Indonesia
}

\author{
Joko Siswanto \\ Department of Political and Social \\ Sciences \\ Sriwijaya University \\ Palembang, Indonesia
}

\begin{abstract}
Indonesian women face structural and cultural barriers to running for the legislator. Although a quota reserves a minimum of 30 percent of parliamentary seats for women, political-party culture tends to exclude women. Introduced via legislation (Law No. 12/2003), the legal candidate quota stipulated that: Each participating political party may nominate candidates for the Dewan Perwakilan Rakyat (National House of Representatives), Dewan Perwakilan Rakyat Daerah (Regional House of Representatives), and Dewan Perwakilan Rakyat Daerah Provinsi, Kabupaten dan Kota (People's Representative Council Provincial and District/City level), for each electoral district, giving consideration to representation of women of at least 30 percent. The results were disappointing for those hoping for a quick bounce in the number of women elected to parliament. Once elected, women legislators need support, training, and advice in navigating the institution of parliament. Training should be provided in the core responsibilities of legislators: constituent relations, legislative duties, and executive oversight, including consideration of national budgets. Capacity building for women legislators will be held in three steps, first, identify women legislators background such as education, political experiences, family background and motivation, second design capacity building that needy women, and the last implementing model of capacity building. This paper will cover the first step by identifying women legislators such as education, age, and experiences in the legislator election process, involvement in political parties, and activities in interest groups
\end{abstract}

Keywords - women legislators, capacity building, democracy

\section{INTRODUCTION}

\section{A. Background}

Preliminary background year 2019 is the political year in Indonesia because in that year was first held a general election simultaneously namely Pilpres and Pileg for DPR, DPD, Provincial DPRD, and city/district DPRD. The Democratic feast that was held on 17 April 2019, has entered a long campaign period compared to the previous elections. Every time a legislative election activity is held, the issue of women's representation always arises and attracts many parties to discuss. There is an affirmative policy that requires each political party to provide kuota $30 \%$ of women's candidates, giving a great opportunity for women to be engaged in legislative institutions either in central, provincial, and city/district. At the center of 16percent election participants successfully meet the quota of 30 percent female Caleg. At the level of Sumatera-South Province as an example of the number of female Caleg 406 while male Caleg reaches 608.

The year 2019 is the political year in Indonesia because in that year was first held a general election simultaneously namely Pilpres and Pileg for DPR, DPD, Provincial DPRD, and city/district DPRD. The Democratic feast that was held on 17 April 2019, has entered a long campaign period compared to the previous elections. Every time legislative election activity is held, the issue of women's representation always arises and attracts many parties to discuss. There is an affirmative policy that requires each political party to provide kuota $30 \%$ of women's candidates, giving a great opportunity for women to be engaged in legislative institutions, at the center, province, and city/district.

At the center of the city, 16 elections participants successfully meet the quota of 30 percent female caleg. At the level of Sumatera-South Province as an example number of female candidates is 406 while male candidates reach 608 people, to fight for 75 seats in DPRD. This means that the female caleg in PARLIAMENT of Sumsel amounted to $40 \%$ of the total number of caleg, and has exceeded the quota as recommended in political party regulation. But, a large number of female candidates are not directly proportional to the opportunity to occupy legislative institutions, as it depends also on the order of candidacy in the Caleg. The struggle of the female candidate is not easy besides having to compete with a male candidate, female candidates still often experience discrimination from both men and society in general. Even female caleg is only considered to meet a $30 \%$ quota only.

With the policy of affirmative and began to be affected by women, the female candidates themselves must have a strong motivation to be able to be equal to men in the legislature. Because with strong motivation will grow competence that is reliable as part of the policymaker. Various efforts were made by political parties, women's organizations and NGOS' moving to increase the capacity of legislative members. From various findings in some areas, there is still a tendency to the level of active women 
in legislative institutions are still low. The personal quality issues of women's legislative members in delivering proposals are important factors that determine whether male members will support the proposal of female members or not, in addition to the lack of confidence of members Female legislature for that need to be pursued through various practical activities by designing accordingly. The needs of female legislative in South Sumatera are urgent to be known before formulating on a strategy or model. it is necessary to know the motivation of the female members' legislative first. The motivation itself will be heavily influenced by various factors such as the formal educational background Political socialization experiences and the background of social and political activities prior to being a member of the DPRD.

By looking at the above background, the preliminary research is required to map the background of formal and non-formal education and the background of social and political activities. These preliminary steps are necessary to construct frameworks in capacity-building activities that fit the needs of women's legislative members. This preliminary study was part of a research effort to develop a model for the capacity development of female legislative members, for that study will be formulated in the research question that is "How is the development model The capacity of the women in Sumatera-South? (Study at the regional PARLIAMENT of Sumatera-South and DPRD Kota/district in South Sumatera province).

\section{B. A glimpse of the Province of South Sumatera}

It since centuries ago also known as Bumi Sriwijaya, in the 7th century until the 12th century AD is the center of Sriwijaya kingdom which is also famous for its Largest and strongest maritime empire in Nusantara. Gaung and his influence even reached Madagascar on the African continent. From the 13th to the 14th centuries, the region was under Majapahit rule. Furthermore, this area once became a landless area and the pirate Bersarini from overseas especially from China in the early 15 th century, the Sultanate of Palembang ruled to the advent of Western colonialism, then followed by the Japanese. While still successful, Sriwijaya kingdom also made Palembang as the Kingdom City.

South Sumatra Province is geographically located between $1-4^{\circ}$ south latitude and $102-106^{\circ}$ east longitude, and the total area of the region is $87.017 .41 \mathrm{~km}^{2}$.

Boundary limit of South Sumatra province as follows:

1. North borders the Jambi province,

2. South borders the province of Lampung,

3. To the east is bordered by Bangka Belitung

4. To the West borders Bengkulu province.

Administratively, South Sumatera province consists of 12 regencies and 4 municipal governments, along with the devices of the regional people's representative. District and city governments overtake the sub-district and village/Kelurahan governments. The district/city government is as follows :

1. Kab. Ogan Komering Ulu (capital of Baturaja)
2. Kab. Ogan Komering UluTimur (capital Martapura)

3. Kab. Ogan Komering UluSelatan (capital of Muara Dua)

4. Kab. Ogan Komering Ilir (the Great Timber Capital)

5. Kab. Enim Estuary (capital Muara Enim)

6. Kab. Lahat (capital of Lahat)

7. Kab. Musi Rawas (the capital of Muara Beliti)

8. Kab. Musi Banyuasin (the Sekayu Capital)

9. district. Banyuasin (Balai Pangkalan capital)

10. Kab. Four Lawang (high capital)

11. Ogan Ilir City (capital Indralaya)

12. Kota Palembang (capital of Palembang)

13. City of Pagar Alam (capital of Pagar Alam)

14. City of Lubuk Linggau (capital of Lubuk Linggau)

15. Kota Prabumulih (capital Prabumulih)

16. Regency of Panukal Abab Lematang Ilir (capital of Talang Ubi)

In the year 2017 the population of South Sumatra has reached 8,266,983 inhabitants, which placed South Sumatera as the 6th Province of Indonesia's largest population, BPS. The total population of South Sumatra continues to grow from year to year.

The number of religions that this discussion includes only 5 religions: Islam, Khatolik, Christianity, Buddhism, and Hinduism. In the year 2003 the percentage of followers of Islam religion of 95.16 percent, Buddha 1.53 percent, catholic 1.29 percent, Kristen 1.16 percent, and Hinduism 0.86 percent.

As with the province, South Sumatra province is divided into districts and cities. Regency/city divided into subdistrict. Sub-districts are divided into villages. Villages and Kelurahan. The number of villages in South Sumatra was 343. And the number of sub-districts 149.

\section{Regional legislative Agencies}

In Indonesia, there is the House of Representatives (DPR) domiciled in the central government is one of the higher institutions of the state in the Indonesian constitutional system which is a representative institution. The House of Representatives consisted of members of the political party elections elected through elections.

The provincial House of Representatives (abbreviated Provincial PARLIAMENT) is the representative institution of the regional people who are based as an element of organizing the provincial government. The provincial PARLIAMENT consists of members of the political party of elections elected by the general elections. The provincial DPRD has the function of legislation, budget and supervision carried out in the framework of the representation of people in the province. The latest legislation governing the provincial PARLIAMENT is the law of the Republic of Indonesia No. 17 the year 2014 
concerning the People's Consultative Assembly, House of Representatives, Regional Representative Council, and the regional House of Representatives who have Changed twice. The First Amendment is made with the laws of the Republic of Indonesia number 42 the year 2014, The second amendment is done by the law of the Republic of Indonesia number 2 the year 2018. The provincial DPRD member amounts to at least 35 (thirty-five) people and at most 100 (one hundred) people with a tenure of 5 (five) years and ends at the time of the new provincial PARLIAMENT member who said the oath/pledge. The provincial DPRD membership was inaugurated with the Decree of Interior Minister.

The House of Representatives of the Regency/city (abbreviated as District DPRD/city) is a representative institution of the regional people who are domiciled as an element of government district/city. The Regency/city DPRD consists of members of the political party elections elected by elections. Members of the district/city DPRD amounting to at least 20 (twenty) people and at most 50 (fifty) people with the term of the District DPRD/City member is 5 (five) years and end when the member of the district/city DPRD has just said Oath/pledge. Membership of the District DPRD is inaugurated with the decision of Governor.

The provincial and Regency/city DPRD has the following authority and duties:

1. Form provincial regulations with the Governor;

2. Discuss and give consent to the draft of regional regulations on the provincial income and expenditure budget proposed by the Governor;

3. Supervise the implementation of local regulations and the provincial income and expenditure budget;

4. Propose the appointment and termination of the Governor and/or deputy Governor to the President through the Minister of Home Affairs to obtain the endorsement of the Rapture and/or termination;

5. Elected deputy governor in the event of a vacancy of Deputy Governor;

6. Give opinions and considerations to provincial governments against international treaty plans in the region;

7. To give consent to international cooperation plans conducted by provincial governments;

8. Request a statement of Governor's accountability in organizing provincial government;

9. Give consent to the plan of cooperation with other regions or with third parties weighing communities and regions;

10. Seeking to implement regional obligations in accordance with the provisions of the legislation;

11. and perform the authority and other duties governed by the provisions of the legislation.

\section{Provincial and Regency/city legislative Rights}

1. The right to Interpellation is the right of District DPRD/city to ask the Regent/mayor about the policy of important and strategic district government and has a wide impact on the life of society and State;

2. The right to poll the right of district DPRD/city to investigate the policy of important and strategic district government and the broad impact on the lives of people, regions, and countries that allegedly contradicts the provisions of the legislation; and

3. The right of stating the right of the opinion of the district/city DPRD to express opinions on the policy of Regent/mayor or about the extraordinary events occurring in the area accompanied by recommendations of settlement or as follow-up implementation The right to Interpellation and right of the poll.

The rule of the election system is listed in article 138 ACT No. 2 the year 2018. Here it reads:

(2) Elections to choose the members of PARLIAMENT, provincial DPRD, and district/city DPRD implemented with a limited open proportional system

(3) The limited open proportional system as referred to in paragraph (2) is the electoral system that uses a proportional system with the list of open candidates and the list of candidate sequential numbers bound by the establishment of the political party mechanics Then explained in the appendix. The following explanation in election LAW in Article 138: "List of candidates open" is a list of candidates for DPR, The provincial DPRD, and the district/city DPRD are listed in the voting letter of the DPR members ' elections, provincial DPRD, and the district/city DPRD respectively stipulated by the political party. The "list of bound candidate sequential numbers" is a list of sequential numbers of candidates for DPR, Provincial DPRD, and Regency/city DPRD which are fixed by consecutive political parties. The election 2014 was held with the open proportional system, which is the selector could take the name of the candidate in addition to the legislative members of the party. Meanwhile, a closed proportional system means the selector just vote the party image.

A limited open proportional system proposed by the Government is a mixture of both. Voters can see the list of prospective legislative members in the party but the order of the candidates remains the party's authority.

Ardi, Anis Maryuni, women in legislative: advocacy for women Legislative Affairs in the House of Representatives of the East Java region, the Journal of Young Politics, Vol. 3 No. 3, August-December 2014, 303-318. The study conducted an exploration and description of the role of women's legislative and all its servants in advocacy for the constituents. The ability of women in advocacy interests in the electoral district II (Pasuruan-Probolinggo) from the results of the analysis that has been legalized, the absorption of legislative women in advocacy interest in the region indicates the capability significantly. But structural-formal, cultural, and personal barriers coupled with the complex 
patriarchy culture and the public stereotype resulted in the representation of women in political institutions experiencing various stagnation. Through an in-depth interview method, supported by the configuration of data through adequate archives, the study transformed the theory of Hanna Pitkin's representation primarily to strengthen gender politics in political representation. The strategy of women in advocacy proved to rely on the interpersonal and lobbying performance, while fractional instruments facilitate women's legislature to remain on the constitutional route. Women's legislatures should give a harder effort to put a space of femininity on legislative institutions. The political representation of women ensures gender representation in politics reaches a situation that is relevant to public needs. Through the efforts of cauterization of women in the legislature and the constitutional efforts to create a substantive woman's absence concluded that a woman's absence was a necessity for collective welfare. The women's legislative policy refers to the "pro-poor" movement, not just the focus on women and children themselves. Then this substantive representation began to be the beginning of the public belief on women's legislature.

Research conducted by Retno Susilowati titled "Implementation of Affirmative Action policy for women quota in Ogan Ilir Regency South Sumatera Province at the 2019 elections. Qualitative research with the main data source is a document that is In KPU district OI. Of the 16 political parties that participated in the 2019 elections, all nominated women to penetrate the DPRD-district of Ogan Ilir. Judging from the spread of the electoral district is 1-6 electoral district, the percentage of female Caleg relatively high in the sense of many political parties who nominated women more than $30 \%$. PKB, in the I can nominate a deposit of $62 \%$, electoral district 2 as much as $40 \%$, the 3 can reach $50 \%$ electoral districts 4 and 5 respectively at $33.33 \%$ and $42 \%$. Partai Gerindra, PDIP, Golkar, Nasdem, Indonesian change movement, the Working Party, MCC averages ranged from $33.33 \%-42.80 \%$ female Caleg. Judging from the high female nomination at the DPRD, bringing a significant expectation of the election results which can reach a quota of $30 \%$ female membership. Apparently the result of the election that has been set KPU of Ogan Ilir Regency, only 4 women who managed to seize the seat of PARLIAMENT or only $8.88 \%$. This means there is no symmetrical correlation between the number of female caleg and female legislative members.

The special purpose of this research refers to the research question above: mapping the characteristics of women's social political legislative members and to know the needs of the political skills of the members of legislative. The results of the mapping will be compiled a model of capacity enhancement of PARLIAMENT members South Sumatera province.

The Mas'oed view of one's involvement in interest groups and formal institutions is included in conventional political participation. The participation of politics itself according to Samuel P. Huntinton in Miriam Budiardjo is a citizen activity that acts as a private person, meaning to influence decision making by the Government. Participation can be individual and collective, peacefully or by force, legal or illegal, effective, or ineffective. There are several factors that influence political participation such as internal factors such as individual motivation, and social economic factors such as high low level of education and income, and external factors is the closest kind of the family And a spacious environment that is outside of the family. Political participation is not always the intangible institution of political decision-making agency legislation. But being a legislator is an actor who contributes directly to the political decision-making process. It is not surprising to be a legislator is the dreams of individuals who have chosen the world of politics as a region to actualize its potential.

The competition is very strict to enter the realm of the legislative institution, making women always be buried. Although the representation of women in practical politics has been driven in such a way through a variety of policies, the results are still far from satisfactory. According to the Inter-Parliamentary Union (IPU) data, as Scholastica Gerintya cited (2017 at the ASEAN Indonesia level, it ranks sixth on the representation of women in Parliament. While internationally, Indonesia is ranked as 89 from 168 countries, far below Afghanistan, Vietnam, TimorLeste, and Pakistan.

Expressly the right of women to be politically secured in the Convention on the Elimination of any discrimination against women (Convention on the Elimination of All Forms of Discrimination against Women/CEDAW). This Convention has been ratified by the Government of Indonesia through Law No. 7 of 1984 concerning the legality of the Convention on the Elimination of any form of discrimination against women or better known to the Women's Convention on 24 July 1984. Previously, the Indonesian Government had signed the Convention on 29 July 1980, following the Conference of the II Women in Copenhagen. The country's obligations relating to the political rights of women are also found in the general recommendation of the CEDAW Committee No. 23 (16th session year 1997).

1. Convention relating to article 7 and 8 of the Convention of Women;

2. Ensure that political parties and trade unions do not discriminate against women;

3. Identify and carry out temporary special measures to ensure equal participation between women and men;

4. Equal opportunity for women and men to occupy public office based on Elections (public elected positions) (Luhulima 2006)

In Indonesia is also relatively accommodating to the discourse and the demands of women's political representation (as reflected in the Law No. 2 of 2011 on the amendment of LAW Number 2 the year 2008 about the political party and the Act Nomor7 year 2017 About the elections), but it should be realized that the female political expression space is given by the State (and the party elites) is far from the spirit of justice and the military. While setting up a 30 percent quota through the country accommodation has been tested since the 2004 election, but judging from the historical aspect of the growth of women's political representation in Parliament, factual is still in fluctuation. This finding was confirmed from Formappi Research in 2013 which shows only a small fraction of 
female candidates placed on her party on the orderly-named legislative candidates 1 . As an example, of 2,465 total female legislator candidates, only 140 or equivalent to 5.7 percent were getting a sequence number 1 .

Lack of representation of women in politics can be seen from three perspectives or views: First, the conservative opinion that sees women are not worthy to plunge into politics, because the political world is the domain of men. This opinion strengthens the Patriarchate culture. Second: Liberal Progressive, progressive liberal views since the beginning of women have been involved in politics, third: apologetic opinion, this opinion looks at what space or territory needs to involve women and there are territories that are not The involvement of women in it [1].

The efforts to improve women's representation became so important in providing justice for women on her political rights, by producing policies that protected women's political rights. The indicators set by the Millennium Development Goals or MDGs for gender equality are the number of representation of women in Parliament. According to political representatives, referring to [2], women's political representatives can be interpreted as the presence of certain group members (women) in formal political institutions.

One of the studies on the representation of women among them shows that the three main factors that have the most significant influence on the degree of representation of women in institutions whose members are elected are: 1. Electoral system; 2. Role and organization of political parties; 3. Cultural acceptance, including supporting action (affirmative action/affirmative action or positive discrimination) that is mandatory or voluntary [3].

The relationship between legislative institutions and their holdings can be analyzed through two representative perspectives, Ranney presents two distinct perspectives, the theory of freedom and Mandate theory [4]. First, the theory of freedom sees that the representative is elected because it is assumed he is a person who has the ability to recognize and formulate a representative interest. Therefore, representatives gain the trust to do the actions that he thinks is best and do not need to consult all things to the representative. Representatives can behave and act without being strictly tied to the delegate because the representatives have given confidence to the representatives. Secondly, the mandate theory puts that proxy power there because of the mandate of the representatives. Therefore, the actions he took in the Parliament must be in accordance with the wishes of the representatives. In this case, consultation with the constituents becomes important.

The fulfillment of such representations is expected to bring about the influence as Phillips expects in The Politic of Presence [5], namely:

1. Belief or beliefs, i.e. women who are representatives in Parliament will encourage other women that they are able to be in Parliament;

2. The achievement of gender equality between men and women through Parliament;
3. The existence of women in Parliament will champion women's interests and gender issues, shown by gender-sensitive policies;

4. Women in Parliament are expected to provide different colors in politics, with concern and sensitivity to women/gender issues.

The structure of the political institution whose main task of drafting political decisions is better known legislative institutions is the institution that is the target of political parties to seat the best cadres including female cadres. But the problem arises when women have successfully entered the legislative body, the work is often still not prominent even many of them ' drowning ' in the councils that require to propose opinions and proposals. Lack of courage to convey opinions and coupled with the lack of knowledge of the field of politics, social and economic cause female legislative members, not much to speak in the hearing, lack of quality and ability of female members in conveying the idea (goddess. 2010).). Therefore, the increase in the capacity of female legislators should be carried out as an effort to improve the individual ability needed to sustain the duties and functions of board members.

The UNDP (United Nations Development Program) and CIDA (Canadian International Development Agency) in Milen (2004 p. 12-14) provide an understanding of the capacity building as the process by which individuals, groups, organizations, institutions, and communities Improve their ability to (a) produce a performance of basic tasks and functions (core functions solving problems, formulating and realizing the achievement of the objectives, and (b) understand and meet the needs of development In a broader context in a sustainable way. This is in line with the concept of capacity building according to Grindle (1997) which states that capacity development as the ability to perform appropriate tasks effectively, efficiently, and sustainable. Even Grindle mentions that capacity building refers to the improvement in the ability of public sector organizations. Overall the above definition essentially contains similarities in the three aspects as follows: 1) That capacity development is a process, 2) that the process should be carried out at three levels, namely individuals, groups and institution or organization, and 3 ) that the process is intended to ensure the continuity of the Organization through the achievement of the objectives and objectives of the organization concerned. Grindle in Haryono (2009:39) stated that human resource capacity development is "initiatives to develop human resources generally seek the capacity of individuals to carry out their professional and technical responsibilities". Initiatives to develop human resources generally strive to increase the capacity of individuals in conducting professional responsibilities and improving their technical skills.

In conducting individual capacity development, the level of competency or individual capacity can be measured through the concept of Gross, (in Steers 1984 Hal 55) stating that the competency must have in carrying out tasks and functions Governance and development are as follows: 1) knowledge that includes: general knowledge, technical knowledge, work and organization, administrative concepts and methods, and self-knowledge. 2) capabilities that include: management, decision making, communication, 
planning, organizing, controlling, working with others, handling conflicts, intuitive minds, communication, and learning. 3) Objectives include orientation of action, confidence, responsibility, and norms, and ethics.

Capacity Building is not a process that departs from scratch or absence, but rather starts from establishing existing potential to be processed so that it will increase the quality of self, group, organization, and system to stay in the middle constantly changing environments. Capacity Building is not only intended for achievement of quality improvement on one component or part of the system only but for all components, not partial but holistic, because Capacity Building is multi dimension and dynamic which is characterized by the existence of multi activities and learning for all components of the system that leads to the contribution of the realization of joint performance (collective performance).

The success of board members in carrying out its functions is determined by many factors. Not all these factors and problems are easily intervened and handled quickly in the short term. Increasing the ability of board members through a series of structured efforts (workshops, tech, training, mentoring, etc.), is regarded as one of the easiest ways of handling and policies relatively easier to implement. This is also considered as something most realistic, considering the work period of the DPRD members relatively short, which is only five years (although there remains an opportunity to be re-elected in the next period). But it must be acknowledged that the overall effort has not been made as expected. It may be related to the design of activities and learning methods that have been implemented during this time. If referring to the circular letter of the Ministry of Home Affairs No. 160/3559/SJ, dated July 9, 2013, concerning technical indicators of orientation and task deepening of provincial DPRD members and Regency/City DPRD, mentioned that the form of activities for the improvement of Ability of the DPRD, broadly, divided into two, namely the orientation and deepening of the task. Task study consists of training activities, technology, workshops, seminars, socialization,

and workshop (https://batukarinfo.com/system/files/Kertas Posisi Menata Ulang Upaya Peningkatan Kapasitas Anggota DPRD.pdf Retrieved 29-9-2019\}

The study related to the analysis of the capacity development model of the female legislature in South Sumatera (study at DPRD South Sumatera province and DPRD Kota/Regency in South Sumatera province) using research and development. The following research discusses the mapping of formal and non-formal educational background and the background of political experiences and social organizations.

Therefore, it needs to improve its capacity in order to play an active role as a part of decision making. A model that is suited to the needs will have a positive impact on the female legislative members. Nextdoor presented research Roadmap regarding capacity development model

\section{RESEARCH METHODS}

Research on the capacity development model for female legislative members in South Sumatera (study in the DPRD in South Sumatera province and DPRD Kota/district in South Sumatera province) is a qualitative study of research About the social and political background of women's legislative members. Exploratory research aims to find something new in the form of grouping a particular symptom or fact. Primary Data are documents obtained from the KPU as an election organizer. Interviews with female legislative members of the period 2019-2024 will be conducted to obtain social background data and political experience. The study of Libraries (literature study) on strategies to empower women members of legislative.

\section{RESULTS AND DISCUSSION}

\section{A. Representation of women in the DPRD province of South Sumatera}

The development of the female LEGISLATOR from 2004-2019 as follows

TABLE I. THE DEVELOPMENT OF THE FEMALE LEGISLATOR

\begin{tabular}{|l|l|l|l|l|l|l|}
\hline & Election & Female & \% & Male & \% & Amount \\
\hline 1 & 2004 & 16 & 21,33 & 59 & 78,67 & 75 \\
\hline 2 & 2009 & 11 & 14,66 & 64 & 85,34 & 75 \\
\hline 3 & 2014 & 12 & 16 & 63 & 84 & 75 \\
\hline 4 & 2019 & 16 & 21,33 & 59 & 78,67 & 75 \\
\hline
\end{tabular}

The highest achievement of women in the DPRD occurred in the results of the 2004 and 2019 elections that reached $21.33 \%$ and the lowest occurred in the election results of 2009 which is at $11.66 \%$. Compared with the affirmative action policy of $30 \%$, the achievement in South Sumatera province is still far below expectations. But if it is

TABLE II. FEMALE PERCENTAGE IN LEGISLATIVE

\begin{tabular}{|l|l|l|l|}
\hline No. & $\begin{array}{l}\text { DPR/DPRD } \\
\text { Province }\end{array}$ & $\begin{array}{l}\mathbf{2 0 1 4 -} \\
\mathbf{2 0 1 9}\end{array}$ & $\begin{array}{l}\mathbf{2 0 1 9 -} \\
\mathbf{2 0 2 4}\end{array}$ \\
\hline 1 & DPR & 17 & 19,48 \\
\hline 2 & $\begin{array}{l}\text { The } \\
\text { Provincial } \\
\text { average }\end{array}$ & 16.32 & - \\
\hline 3 & $\begin{array}{l}\text { South } \\
\text { Sumatera }\end{array}$ & 16 & 21,33 \\
\hline
\end{tabular}

seen from the average provincial DPRD se Indonesia which is only $15.85 \%$. South Sumatera Province has been above the average with $21.33 \%$ achievement.

As comparator in both the central level of DPR and the achievement of several provinces in the following table:

\begin{tabular}{|l|l|l|l|}
\hline 4 & DKI & 15,23 & 19,81 \\
\hline 5. & $\begin{array}{l}\text { North } \\
\text { Sumatra }\end{array}$ & 12 & 13 \\
\hline 6. & West Java & 19 & 17,5 \\
\hline 7 & $\begin{array}{l}\text { East } \\
\text { Kalimantan }\end{array}$ & 12,72 & 18,18 \\
\hline 8. & Maluku & 26,66 & 17,77 \\
\hline 9 & $\begin{array}{l}\text { West Nusa } \\
\text { Tenggara }\end{array}$ & 7,69 & - \\
\hline
\end{tabular}


It is seen that in Indonesia the representation of women is still under the direction of affirmative policy of $30 \%$. The ASEAN Indonesia level ranks 6 (six), under Laos, Vietnam, Singapore, and Cambodia. The top is the Philippine among the ASEAN countries.

Judging from the origin of the political party, in the province of South Sumatera, since the elections 2004, 2009 and 2014, 7 political parties managed to deliver the woman to the board, but in the election of 2019, PAN was unable to maintain the political cadres in the DPRD, so that only 6 The surviving party has its representatives. Judging by the number, the PKB has a significant increase in the election of 2019, which is able to put 3 people from the previous one who only managed to put 1 person. Gerindra Party had a tidal tide, especially the results of the 2009 elections did not succeed at all placing the political cadres at legislative but experienced a surge in the 2014 election, so it can, returning like the election results from 2014. Likewise, the PDIP, a decline in the election 2009 and 2014, achievement in the 2019 election was very significant with 5 people succeeded and the most party put women in the DPRD. Nasdem Party is constantly only able to bring 1 female, the Democratic Party was once the most contributor of women in the legislature in the period 2009-2014 that is as many as 5 people or $45.45 \%$, but experienced a loss Quite significant in the 2 consecutive periods that the election results from 2014 and 2019 only able to deliver 2 cadres only.

\section{B. Women member profile of DPRD election results from 2019}

TABLE III. BY POLITICAL PARTY, THE ORIGIN OF THE CANDIDATE, THE SEQUENCE NUMBER OF CANDIDACY AND VOTING

\begin{tabular}{|l|l|l|l|l|l|}
\hline No. & Name & $\begin{array}{l}\text { Political } \\
\text { parties }\end{array}$ & $\begin{array}{l}\text { Electoral } \\
\text { district }\end{array}$ & $\begin{array}{l}\text { Sequential } \\
\text { numbers }\end{array}$ & $\begin{array}{l}\text { Voice } \\
\text { acquisition }\end{array}$ \\
\hline 1. & $\begin{array}{l}\text { R.A.Anita } \\
\text { Noeringhati }\end{array}$ & Golkar & 1 & 1 & 16.801 \\
\hline 2. & Sumiati & PDIP & 3 & 6 & 8733 \\
\hline 3. & $\begin{array}{l}\text { Meli } \\
\text { Mustika }\end{array}$ & PDIP & 3 & 3 & 31.394 \\
\hline 4. & $\begin{array}{l}\text { Ike Maya } \\
\text { Sari }\end{array}$ & PDIP & 3 & 1 & 30.831 \\
\hline 5 & Nilawati & PKB & 4 & 1 & 32.535 \\
\hline 6. & Lindawati & Golkar & 4 & 1 & 23.484 \\
\hline 7. & Susilawati & Gerindra & 5 & 1 & 11.652 \\
\hline 8. & $\begin{array}{l}\text { Tina } \\
\text { Malinda }\end{array}$ & PDIP & 5 & 1 & 17.133 \\
\hline 9. & Yeni Elita & Nasdem & 5 & 1 & 30.528 \\
\hline 10. & Nurhiliyah & PKB & 6 & 1 & 9836 \\
\hline 11. & $\begin{array}{l}\text { Lia } \\
\text { anggraini }\end{array}$ & Demokrat & 6 & 3 & 18.232 \\
\hline 12. & Haldo & Demokrat & 6 & 1 & 16.472 \\
\hline 13. & $\begin{array}{l}\text { Rita } \\
\text { Suryani }\end{array}$ & PDIP & 8 & 5 & 21.825 \\
\hline 14. & $\begin{array}{l}\text { Kartika } \\
\text { Sandra }\end{array}$ & Gerindra & 9 & 1 & 16.337 \\
\hline 15 & Susi Imelda & PDIP & 9 & 4 & 24.134 \\
\hline 16. & $\begin{array}{l}\text { Nadya } \\
\text { Basyir }\end{array}$ & Golkar & 10 & 1 & 25.211 \\
\hline
\end{tabular}

From the acquisition of the above 4 board members were able to occupy ranks $4,5,6$, and 8 of 75 members with votes above 30,000. Judging from the order of candidacy, 11 people occupy the 1 st place, while the remaining 5 are on the order of $3,4.5$ and 6 . Thus the sequence number does not guarantee easier to be elected as a member of PARLIAMENT, this is simplified with the photo of Caleg that will facilitate voters compared to the sequential number.
Experience in the management of the political party, 12 women members of PARLIAMENT were party admins who had long enough to exist in the Parpol, but they held a position very closely with tasks labeled as the task of the People Women empowerment and Social Affairs. In addition to the active management of political parties they are also active in party wing organization.

TABLE IV. JUDGING BY THE LAST EDUCATION

\begin{tabular}{|c|c|c|c|}
\hline Election & $\begin{array}{c}\text { Senior } \\
\text { High } \\
\text { School }\end{array}$ & $\begin{array}{c}\text { Under } \\
\text { graduate }\end{array}$ & $\begin{array}{c}\text { Master } \\
\text { degrre }\end{array}$ \\
\hline 2004 & 0 & 10 & 6 \\
\hline 2009 & 0 & 7 & 4 \\
\hline 2014 & 0 & 8 & 4 \\
\hline 2019 & 3 & 7 & 6 \\
\hline
\end{tabular}

Judging from the last education, the educational background of board members can be relatively high with master achievements more than $50 \%$ at every term. This means having a basic capital as part of a policy maker. 
TABLE V. BACKGROUND OF DPRD MEMBERS JUDGING BY EXPERIENCE IN LEGISLATIVE

\begin{tabular}{|c|c|c|c|c|}
\hline No. & Name & $\begin{array}{l}\text { Political } \\
\text { parties }\end{array}$ & Period & $\begin{array}{l}\text { Membership } \\
\text { Experience }\end{array}$ \\
\hline 1. & $\begin{array}{l}\text { R.A.Anita } \\
\text { Noeringhati }\end{array}$ & Golkar & $\begin{array}{c}2004- \\
2009 \\
2009- \\
2014 \\
2014- \\
2019 \\
2019- \\
2024\end{array}$ & Fourth period \\
\hline 2. & Sumiati & PDIP & $\begin{array}{c}2004- \\
2009 \\
2009- \\
2014 \\
2019- \\
2024 \\
\end{array}$ & Third period \\
\hline 3. & $\begin{array}{l}\text { Meli } \\
\text { Mustika }\end{array}$ & PDIP & $\begin{array}{c}2019- \\
2024\end{array}$ & First period \\
\hline 4. & $\begin{array}{ll}\text { Ike } & \text { Maya } \\
\text { Sari } & \end{array}$ & PDIP & $\begin{array}{c}2004- \\
2009 \\
2019- \\
2024 \\
\end{array}$ & $\begin{array}{l}\text { Second } \\
\text { period }\end{array}$ \\
\hline 5 & Nilawati & PKB & $\begin{array}{c}2004- \\
2009 \\
2009- \\
2014 \\
2014- \\
2019 \\
2019- \\
2024\end{array}$ & Fourth period \\
\hline 6. & Lindawati & Golkar & $\begin{array}{c}2009- \\
2014 \\
2019- \\
2024\end{array}$ & $\begin{array}{l}\text { Periode } \\
\text { kedua }\end{array}$ \\
\hline 7. & Susilawati & Gerindra & $\begin{array}{c}2004- \\
2009 \\
2014- \\
2019 \\
2019- \\
2024 \\
\end{array}$ & Third period \\
\hline 8. & $\begin{array}{l}\text { Tina } \\
\text { Malinda }\end{array}$ & PDIP & $\begin{array}{c}2014- \\
2019 \\
2019- \\
2024 \\
\end{array}$ & $\begin{array}{l}\text { Second } \\
\text { period }\end{array}$ \\
\hline 9. & Yeni Elita & Nasdem & $\begin{array}{c}2019- \\
2024\end{array}$ & First period \\
\hline 10. & Nurhiliyah & PKB & $\begin{array}{c}2019- \\
2024\end{array}$ & First period \\
\hline 11. & $\begin{array}{l}\text { Lia } \\
\text { anggraini }\end{array}$ & Demokrat & $\begin{array}{c}2019- \\
2024\end{array}$ & First period \\
\hline 12. & Holda & Demokrat & $\begin{array}{c}2004- \\
2009 \\
2009- \\
2014 \\
2014- \\
2019 \\
2019- \\
2024 \\
\end{array}$ & Fourth period \\
\hline 13. & $\begin{array}{l}\text { Rita } \\
\text { Suryani }\end{array}$ & PDIP & $\begin{array}{c}2019- \\
2024\end{array}$ & First period \\
\hline 14. & $\begin{array}{l}\text { Kartika } \\
\text { Sandra }\end{array}$ & Gerindra & $\begin{array}{c}2004- \\
2009 \\
2014- \\
2019 \\
2019- \\
2024 \\
\end{array}$ & Third period \\
\hline 15 & Susi Imelda & PDIP & $\begin{array}{c}2019- \\
2024\end{array}$ & First period \\
\hline 16. & $\begin{array}{l}\text { Nadya } \\
\text { Basyir }\end{array}$ & Golkar & $\begin{array}{c}2004- \\
2009 \\
2014- \\
2019 \\
\end{array}$ & Third period \\
\hline
\end{tabular}




\begin{tabular}{|l|l|l|c|l|}
\hline No. & Name & $\begin{array}{l}\text { Political } \\
\text { parties }\end{array}$ & Period & $\begin{array}{l}\text { Membership } \\
\text { Experience }\end{array}$ \\
\hline & & & $\begin{array}{c}2019- \\
2024\end{array}$ & \\
\hline
\end{tabular}

Based on experience in membership in Legislative province, there are interesting variations, 10 people or $62.50 \%$ are incumbent, 6 people or $37.50 \%$ are newcomers meaning for the first time to become a member of the board. The three members of the provincial PARLIAMENT are the fourth time, namely the Golkar party, the PKB and the Democratic Party. For the third time as much as 4 people came from the PDIP, 2 people from Gerindra and 1 person from the Golkar party. There are three women which enters the second period as much as is 2 people from PDIP and 1 person from the Golkar party.
Seen from the age side, one person aged less than 30 years old, 2 persons at the age of 30-39, 3 are of 40-49 years old and at most 8 people are aged 50-60 years. Judging from the age, the majority of women in the DPRD have been mature as women.

\section{Representation of women in District DPRD/cities in South Sumatera Province}

TABLE VI. MEMBER OF DPRD REGENCY/CITY IN SOUTH SUMATERA PROVINCE ELECTION RESULT 2019 BASED ON GENDER

\begin{tabular}{|l|l|l|l|l|l|l|}
\hline No. & Regency/City & Female & $\%$ & male & $\%$ & Amount \\
\hline 1 & Palembang & 4 & 8 & 47 & 94 & 50 \\
\hline 2 & Muara Enim & 7 & 15,55 & 38 & 84,45 & 45 \\
\hline 3 & Ogan Ilir & 4 & 10 & 36 & 90 & 40 \\
\hline 5 & Lahat & 4 & 8,88 & 41 & 91,02 & 45 \\
\hline 6 & $\begin{array}{l}\text { Musi } \\
\text { Banyuasin }\end{array}$ & 3 & 6,66 & 42 & 93,33 & 45 \\
\hline 7 & $\begin{array}{l}\text { Ogan } \\
\text { Komering Ilir }\end{array}$ & 6 & 13,33 & 39 & 86,67 & 45 \\
\hline 8 & Prabumulih & 4 & 16 & 21 & 84 & 25 \\
\hline 9 & Musi Rawas & 8 & 17,77 & 37 & 82,23 & 45 \\
\hline 10 & $\begin{array}{l}\text { Lubuk } \\
\text { Linggau }\end{array}$ & & & & & \\
\hline 11 & OKU Timur & 3 & 6,66 & 42 & 93,33 & 45 \\
\hline 12 & OKU Selatan & 6 & 15 & 34 & 85 & 40 \\
\hline 13 & $\begin{array}{l}\text { Empat } \\
\text { Lawang }\end{array}$ & 3 & 8,57 & 32 & 91,43 & 35 \\
\hline 14 & Banyuasin & 6 & 13,33 & 39 & 86,67 & 45 \\
\hline 15 & Pagar Alam & 4 & 16 & 21 & 84 & 25 \\
\hline 16 & OKU & 6 & 15 & 34 & 85 & 40 \\
\hline
\end{tabular}

Looking at the table above, there are variations in the size of women's success in PARLIAMENT of Regency/municipality from the lowest of Musi Banyuasin Regency (6.66\%) And the highest reached Musi Rawas Regency amounted to $17.77 \%$. The average of women in DPRD membership ranges from $14.2 \%$, thus there are 2 cities and 4 districts above the national average namely, Prabumulih City, Pagar Alam City, Muara Enim Regency, OKU and Musi Rawas regency. There are still 9 districts below the national average.

\section{Capacity development for women members legislative.}

In order to increase the ability of women in legiaslatives, generally issued political parties do political education by internally but these activities do not take place continuously and usually done before The elections so impressed only to meet the quota of $30 \%$, but should women as political cadres were prepared as early as possible before plunging into elections. Women have different attitudes and behaviors with men, this distinction is rarely taken into account by the party to increase its capacity in the political world. Presumably it became a common phenomenon that applies to all political parties in Indonesia that in conducting political education most parties have no sorting between female and male candidates. From the statements of some of the functionaries of the political party which later became the female legislators it was seen that political parties lacked concern for the needs of women politicians. Political parties tend to disguise the political supply material for its cadence. Consequently, the ability of female legislative members is not maximal because they need different psychological forces with men while in the midst of the board members the majority are men. Psychological reinforcement is what still escapes the attention of political parties.

Political parties have similar tendencies. They are too busy and concerned with the number of female legislative candidate so as to win the requirement to qualify to be the election participant party. Indeed, the more important thing to note is to get quality women who have reliable political skills. During this frenzied political party effort in give to enable female cadres concentrated during the election period. Once the election has ended the party tends to be ignore in performing the obligation of conducting political education, an activity that should be the main task of the party.

In Palembang the activities of women's political capacity enhancement have been conducted by the Women Empowerment and child Protection Agency in cooperation with the Coordination Board of Women's and KPU South Sumatera. The general material given is the techniques of communicating with the constituents, strategies and 
processes of supervising and securing sound, as well as the calculation of the sound of the appropriate electoral law.

Post-election activities for capacity building of DPRD members are known as Bimtek implemented by the Center for Training and Education of Ministry of Home Affairs. All members of the provincial LEGISLATORS are obliged to follow the Bimtek with a wide selection of material learning materials, two main materials that are the duties and functions of the DPRD members and the relationship of central and local governments.

\section{CONCLUSION}

The highest achievement of women in the DPRD occurred in the results of the 2004 and 2019 elections that reached $21.33 \%$ and the lowest occurred in the election results of 2009 which is at $11.66 \%$. Compared with the affirmative action policy of $30 \%$, the achievement in South Sumatera province is still far below expectations. But if it is seen from the average provincial DPRD se Indonesia which is only $15.85 \%$. South Sumatera Province has been above the average with $21.33 \%$ achievement.

Experience in the management of the political party, 12 women members of PARLIAMENT were party admins who had long enough to exist in the Parpol, but they held a position very closely with tasks labeled as the task of the People Women empowerment and Social Affairs. In addition to the active management of political parties they are also active in party wing organization.

Based on experience in membership in Legislative province, there are interesting variations, 10 people or $62.50 \%$ are incumbent, 6 people or $37.50 \%$ are newcomers meaning for the first time to become a member of the board. Judging from the last education, the educational background of board members can be relatively high with master degree achievements more than $50 \%$ at every term. This means having a basic capital as part of a policy maker.

Post-election activities for capacity building of DPRD members are known as Bimtek implemented by the Center for Training and Education of Ministry of Home Affairs. All members of the provincial LEGISLATORS are obliged to follow the Bimtek with a wide selection of material learning materials, two main materials that are the duties and functions of the DPRD members and the relationship of central and local governments.

\section{REFERENCES}

Rasyidin and F. Aruni, Gender dan Politik, Keterwakilan Wanita dalam Politik. 2016.

[2] J. Lovenduski, "State feminism and women's movements," West Eur. Polit., vol. 31, no. 1-2, pp. 169-194, 2008.

[3] D. Artina, "Keterwakilan Politik Perempuan dalam Pemilu Legislatif Provinsi Riau Periode 2014-2019," J. Huk. Ius Quia Iustum, vol. 23, no. 1, pp. 123-141, 2016

[4] W. Ichwanuddin, Konsep Perwakilan Politik. 2014.

[5] A. M. ARDI, "Perempuan Di Legislatif: Advokasi Perempuan Legislatif Bagi Kepentingan Dapil Di Dewan Perwakilan Rakyat Daerah Jawa Timur." UNIVERSITAS AIRLANGGA, 2014. 